\title{
Carcass and meat traits, and non-carcass components of lambs fed ration containing increasing levels of urea
}

\author{
Características da carcaça, da carne e dos componentes \\ não-carcaça de cordeiros alimentados com ração contendo \\ níveis crescentes de ureia
}

\author{
Sandra Rozanski ${ }^{1 *}$; Diana Rosana Vivian ${ }^{1}$; Luciana Helena Kowalski1; \\ Odilei Rogerio Prado ${ }^{2}$; Sergio Rodrigo Fernandes ${ }^{3}$; \\ Júlio César de Souza; ${ }^{4}$ José Antônio de Freitas ${ }^{5}$
}

\begin{abstract}
The objective of this study was to evaluate the carcass and meat traits, and the non-carcass components of crossbred Dorper lambs fed diets with increasing levels of urea $(0.0,0.5,1.0$, and $1.5 \%$ of dry matterDM). The experimental design was completely randomized with four treatments (urea inclusion levels) and six replicates per treatment. Lambs were fed ad libitum for 56 days and slaughtered at $37.9 \pm 5.1 \mathrm{~kg}$ of body weight (BW). The weight and yield of carcass before and after cooling were not influenced by urea levels, with average values of $16.9 \mathrm{~kg}$ and $44.6 \%$ for cold carcass weight and yield. Urea levels did not affect the morphometric measurements, the fat deposition on the carcass, the weight of carcass cuts and the weight of non-carcass components. There was a quadratic effect of urea levels on the loin yield, which may achieve maximum value of $11.31 \%$ with the inclusion of $0.84 \% \mathrm{DM}$ urea in the feed. The $\mathrm{pH}$ and the color coordinates $\mathrm{L}^{*}$ (brightness), $\mathrm{a}^{*}$ (red intensity) and $\mathrm{C}^{*}$ (saturation) of the meat also showed quadratic response to the urea levels, where in the minimum value of 5.53 for $\mathrm{pH}$, maximum value of 48.67 for $\mathrm{L}^{*}$ and minimum values of 14.04 and 16.21 for $\mathrm{a}^{*}$ and $\mathrm{C}^{*}$ may be obtained by including 0.53 to $0.70 \% \mathrm{DM}$ urea in the ration. The inclusion of $0.84 \% \mathrm{DM}$ urea in the ration is recommended to obtain maximum yield of loin and meat with attractive characteristics to the consumer, which is characterized by high red intensity and brightness. If consumers have preference for lamb meat with a more intense red color, the inclusion of $1.5 \% \mathrm{DM}$ urea should be considered in the ration formulation.
\end{abstract}

Key words: Color. Feedlot. Loin. Meat quality. Sheep.

\section{Resumo}

Objetivou-se com este estudo avaliar as características de carcaça, dos componentes não-carcaça e da carne de cordeiros mestiços Dorper alimentados com rações contendo níveis crescentes de ureia $(0,0 ; 0,5$; 1,$0 ; 1,5 \%$ da matéria seca-MS). O delineamento foi inteiramente casualizado com quatro tratamentos (níveis de inclusão de ureia) e seis repetições por tratamento. Os cordeiros foram alimentados à vontade

\footnotetext{
${ }^{1}$ Mestres em Ciência Animal, Universidade Federal do Paraná, UFPR, Setor Palotina, Palotina, PR, Brasil. E-mail: sandra rozanski@yahoo.com.br; diana_vivian@hotmail.com; lucianahelenak@gmail.com

2 Prof., Curso de Medicina Veterinária, Universidade Tuiuti do Paraná, UTP, Campus Professor Sydnei Lima Santos, Curitiba, PR, Brasil. E-mail: orpradovet@gmail.com

${ }^{3}$ Pós-doutorando, Programa de Pós-graduação em Ciência Animal, UFPR, Setor Palotina, Palotina, PR, Brasil. E-mail: srfernandes83@gmail.com

${ }^{4}$ Prof., Universidade Federal de Mato Grosso do Sul, UFMS, Campus de Paranaíba, Paranaíba, MS, Brasil. E-mail: julio.souza@, ufms.br

${ }^{5}$ Prof., Departamento de Zootecnia, UFPR, Setor Palotina, Palotina, PR, Brasil. E-mail: freitasjaf@ufpr.br

* Author for correspondence
} 
por 56 dias e abatidos com $37,9 \pm 5,1 \mathrm{~kg}$ de peso corporal (PC). Os pesos e rendimentos de carcaça antes e após o resfriamento não foram influenciados pelos níveis de inclusão de ureia, com valores médios de $16,9 \mathrm{~kg}$ e 44,6\% para peso e rendimento de carcaça fria. Os níveis de inclusão de ureia não afetaram as medidas morfométricas, a deposição de gordura e o peso dos cortes da carcaça; e o peso dos componentes não-carcaça. Houve efeito quadrático dos níveis de inclusão de ureia sobre o rendimento de lombo, que pode alcançar o valor máximo de $11,31 \%$ com a inclusão de $0,84 \%$ MS de ureia na ração. $\mathrm{O} \mathrm{pH}$ e as coordenadas de cor $\mathrm{L}^{*}$ (luminosidade), a* (intensidade de vermelho) e $\mathrm{C}^{*}$ (saturação) da carne também apresentaram resposta quadrática aos níveis de inclusão de ureia, em que o valor mínimo de 5,53 para $\mathrm{pH}$, valor máximo de 48,67 para L* e os valores mínimos de 14,04 e 16,21 para a* e C* podem ser obtidos com a inclusão de 0,53 a $0,70 \%$ MS ureia na ração. Recomenda-se a inclusão de $0,84 \%$ MS de ureia na ração para a obtenção de máximo rendimento de lombo e de carne com características qualitativas atrativas ao consumidor, que é caracterizada pela boa intensidade de cor vermelha e de brilho. Se os consumidores têm preferência por carne ovina com cor vermelha mais intensa, a inclusão de 1,5\% MS de ureia deverá ser considerada na formulação da ração.

Palavras-chave: Confinamento. Cor. Lombo. Ovinos. Qualidade de carne.

\section{Introduction}

The consumption of lamb meat has increased considerably in recent years, mainly due to the supply of high quality meat obtained from young animals. In this aspect, the feedlot practice has been highlighted by the production of meat with superior quality (softness) when compared to that obtained from animals raised on pasture (TURINO et al., 2007), offer of standardized carcasses to the market, and high turnover and financial return (ALVES et al., 2014).

The production of high quality carcasses in feedlot depends on the high performance of lambs, which is maximized by providing properly balanced diets with energy and protein levels that favor high deposition of muscle tissue and enough fat deposition to meet consumer demand. On the other hand, this practice presents high production costs, once feeding is the most expensive component of the variable cost in animal production, representing between 80 and 90\% (ALMEIDA et al., 2011). Among the ingredients used in large scale in ruminant nutrition, protein sources such as soybean meal and cottonseed meal are the most expensive (CLEMENTINO et al., 2007). Thus, the use of alternative protein sources is a way to minimize the costs of finishing lambs in feedlot.

Urea is an alternative food widely used in diets for ruminants (CANBOLAT; KARABULUT, 2010), as a nitrogen source capable of supplying half the nitrogen requirements of rumen microorganisms, replacing conventional protein sources; due to its easy and rapid degradation in the rumen, promoting an efficient synthesis of microbial protein of high biological value; and low cost per unit of supplied protein (JENKINS et al., 2011). According to Chalupa (1968) for maximum urea utilization there must be $1 \%$ nitrogen in the total dry matter (DM) of diet, or $33 \%$ of the total dietary protein from non-protein nitrogen (NPN) of urea. However, the performance of feedlot lambs is not reduced when 1.7 to $1.95 \%$ of urea is added to the diet on DM basis (MAGALHÃES et al., 2006).

The carcass is the most valuable item in the commercialization of sheep. Different diets, its levels of energy and protein, and the finishing on pasture or in feedlot, among other factors, may affect the carcass traits (NÚÑEZ et al., 2007) and the development of non-carcass components (ANDRADE et al., 2009). Moreover, the inclusion of urea and different sources of true protein in the diet can influence the quality of the meat by modifying the chemical composition and growth of muscle tissues (ALVES et al. 2014).

Despite being described in literature the effects of feeding on a lambs carcass and meat characteristics, there is still little information about the use of alternative foods such as urea, especially 
in intensive production systems. In this context, this study examined the influence that the inclusion of urea in the ration has on carcass and non-carcass traits, and meat quality of feedlot lambs.

\section{Material and Methods}

\section{Experimental protocol}

The research and procedures conducted on animals are in accordance with the Ethical Principles in Animal Experimentation adopted by the Colégio Brasileiro de Experimentação Animal (COBEA), and was approved by the Comissão de Ética no Uso de Animais (CEUA) of the Universidade Federal do Paraná (UFPR), Palotina Campus, with the protocol number 08/2012-CEUA issued by this institution.

The research was conducted at the Centro de Estudos em Pequenos Ruminantes (CEPER) of Palotina Campus, UFPR, located in Palotina, Paraná
State, Brazil. Twenty four crossbred Dorper lambs were used with $25.0 \pm 4.3 \mathrm{~kg}$ (average \pm standard deviation - SD) of body weight (BW) and 3.5 months of age at the beginning of the experiment. The animals were identified with ear tags, weighed and housed in individual pens with $1.5 \mathrm{~m}^{2}$ of area, slatted floor, automatic waterer and individual feeder.

The experimental design was completely randomized, with four treatments and six replications. The treatments were the inclusion of $0.0 ; 0.5 ; 1.0$ and $1.5 \%$ urea in the ration on DM basis. The ration consisted of Tifton 85 hay (Cynodon spp) and concentrate feed (Table 1).

The adaptation period to the facility, management and diet was 15 days, and the trial period was 56 days under an environmental condition of $22.8{ }^{\circ} \mathrm{C}(73.04$ ${ }^{\circ} \mathrm{F}$ ) of temperature and $74.7 \%$ of relative humidity, on average. The rations were isoproteic with $17.03 \pm$ $0.13 \%$ DM of crude protein (CP; Table 1 ).

Table 1. Proportion of ingredients and nutritional composition of the ration provided to feedlot lambs during the trial.

\begin{tabular}{|c|c|c|c|c|}
\hline \multirow{2}{*}{ Composition $^{\mathrm{I}}$} & \multicolumn{4}{|c|}{ Urea (\% DM) } \\
\hline & 0.0 & 0.5 & 1.0 & 1.5 \\
\hline Tifton 85 hay $(\% \mathrm{DM})$ & 36.0 & 40.0 & 34.0 & 25.0 \\
\hline Concentrate feed (\% DM) & 64.0 & 60.0 & 66.0 & 75.0 \\
\hline $\mathrm{CPC}(\% \mathrm{DM})^{\mathrm{II}}$ & 58.0 & 33.5 & 15.0 & 26.0 \\
\hline Soybean hulls (\% DM) & 5.0 & 25.0 & 49.0 & 19.0 \\
\hline Ground corn grain $(\% \mathrm{DM})$ & 0.0 & 0.0 & 0.0 & 27.5 \\
\hline Mineral premix (\% DM) ${ }^{\mathrm{III}}$ & 1.0 & 1.0 & 1.0 & 1.0 \\
\hline Urea $(\% \mathrm{DM})$ & 0.0 & 0.5 & 1.0 & 1.5 \\
\hline DM (\%) & 86.70 & 87.90 & 89.50 & 88.52 \\
\hline $\mathrm{CP}(\% \mathrm{DM})$ & 16.85 & 17.01 & 17.17 & 17.07 \\
\hline $\mathrm{EE}(\% \mathrm{DM})$ & 2.29 & 2.24 & 2.24 & 2.63 \\
\hline NDF (\% DM) & 28.55 & 44.75 & 56.63 & 32.71 \\
\hline $\mathrm{Ca}(\% \mathrm{DM})$ & 0.97 & 0.79 & 0.69 & 0.64 \\
\hline $\mathrm{P}(\% \mathrm{DM})$ & 0.46 & 0.35 & 0.27 & 0.36 \\
\hline Ca: P & 2.10 & 2.26 & 2.56 & 1.88 \\
\hline TDN (\% DM) & 65.03 & 63.00 & 63.00 & 68.80 \\
\hline ME $\left(\right.$ Mcal kg DM $\left.{ }^{-1}\right)$ & 2.36 & 2.27 & 2.27 & 2.48 \\
\hline
\end{tabular}

${ }^{\text {I }}$ DM: dry matter; CP: crude protein; EE: ether extract; NDF: neutral detergent fibre, Ca: calcium; P: phosphorus; Ca: P: Ca: P ratio; TDN: total digestible nutrients; ME: metabolizable energy

II $\mathrm{CPC}$ - commercial pelleted concentrate: $87 \% \mathrm{DM} ; 18 \% \mathrm{CP} ; 2.5 \% \mathrm{EE} ; 9 \%$ of crude fibre; $10 \%$ of ash; $0.15 \% \mathrm{Ca} ; 0.06 \% \mathrm{P} ; 0.05 \%$ $\mathrm{Na} ; 100$ ppm BHT; 20 ppm Co; 45 ppm Cu; 55 ppm Fe; 10 ppm I; 50 ppm Mn; 0,3 ppm Se; 1,000 UI Vit A; 5,800 UI Vit D; 600 UI Vit E

III $1.2 \% \mathrm{Mg} ; 13.3 \% \mathrm{Na} ; 1 \% \mathrm{~S} ; 6.5 \% \mathrm{P} ; 16.2 \% \mathrm{Ca} ; 2,250$ ppm Mn; 86 ppm Cu; 1,400 ppm Fe; 200 ppm Co; 23 ppm Se; 4,500 ppm Zn; 177 ppm I; 100,000 UI Vit A; 65,000 Vit $\mathrm{D}_{3}$; 60 UI Vit E. 
Diets were fed as total mixed ration (TMR) and fractionated in two daily offers (08h00 and 14h00). Hay was shredded in particles of approximately 3 $\mathrm{cm}$ length to improve the utilization by the animals and reduce waste in the trough. The animals were fed ad libitum in the adaptation period and during the trial, keeping the orts in the trough at $10 \%$ of the amount of ration provided. Adjustments on the amount of ration provided were performed every five days based on the amount of orts.

On the first day of the trial period the animals were weighed after fasting (withdrawing feed for $12 \mathrm{~h}$ ) in a scale with precision of $200 \mathrm{~g}$. The trial period (56 days) was defined as the time required for the average animal slaughter BW to be reached, approximately 35 $\mathrm{kg}$ corresponding to the average $\mathrm{BW}$ for slaughtering lambs in the region (30 to $40 \mathrm{~kg}$ ).

\section{Assessments}

The evaluation of the in vivo carcass composition was performed by measuring the ribeye area $\left(\mathrm{REA}_{\mathrm{US}}\right)$ and backfat thickness $\left(\mathrm{BFT}_{\mathrm{US}}\right)$ by ultrasound. The image capture was performed on the $30^{\text {th }}$ and $56^{\text {th }}$ day of the trial with the Landwind ultrasound model C40, equipped with electronic linear transducer $(7 \mathrm{~cm}$ in length and frequency of 7.5 MHz). After shaving the wool and cleaning the skin in the region between the $12^{\text {th }}$ and $13^{\text {th }}$ thoracic vertebrae, the ultrasound images were captured using vegetable gel to provide better transducer coupling, conductivity and higher quality images. The transducer was equipped with an acoustic guide and was arranged perpendicularly to the length of Longissimus lumborum (L. lumborum), to enable the measurement of REA $\mathrm{RS}_{\mathrm{US}}\left(\mathrm{cm}^{2}\right)$ and $\mathrm{BFT}_{\mathrm{US}}(\mathrm{mm})$, the latter being measured at $3 / 4$ away from the medial position to the lateral position of muscle in relation to the midline. The images were identified with the ear tag number of each animal, digitalized with specific software that accompanies the equipment, and stored on a hard disk for further analysis and interpretation. The $\mathrm{REA}_{\mathrm{US}}$ was calculated on the AutoCAD ${ }^{\circledR}$ software.
Upon reaching the preset slaughter weight, lambs were kept fasting (withdrawing feed for $16 \mathrm{~h}$ ), weighed for recording the body weight at slaughter (SW) and sent to a commercial slaughterhouse in the region. The slaughter procedure was made by stunning the animals, followed by bleeding (performed by severing of the jugular veins and carotid arteries) and skinning to remove the skin. Blood was stored in a container and the head, paws and skin were removed and subsequently the four components were weighed individually. After, the gutting was performed followed by the collection of internal organs, which were sent to the Laboratório de Anatomia Patológica of Palotina Campus, UFPR. The internal organs were separated in heart, lungs + trachea, liver + gallbladder, spleen, kidneys, adipose deposits (omental, mesenteric, pelvic and perirenal fat) and gastrointestinal tract (GIT). The GIT was weighed with the digestive contents (DC) and later was individualized in rumen + reticulum, omasum, abomasum and intestine (small and large). All the organs were weighed individually, and after weighing the organs of GIT were emptied. The empty GIT organs were weighed and their yield relative to GIT and in relation to the empty body weight (EBW, obtained by the difference between SW and DC) was calculated.

After the slaughter, carcasses were weighed to record the hot carcass weight (HCW), identified and suspended by the metatarsal joints. The $\mathrm{pH}$ of the carcasses was measured 45 minutes after slaughter $\left(\mathrm{pH}_{\mathrm{PS}}\right)$ with a $\mathrm{pH}$ meter introduced in L. lumborum muscle between the $4^{\text {th }}$ and $5^{\text {th }}$ lumbar vertebrae. Then the carcasses were transferred to a cold room at $4{ }^{\circ} \mathrm{C}$, where they remained for $24 \mathrm{~h}$. Post cooling, the $\mathrm{pH}$ was again measured $\left(\mathrm{pH}_{\mathrm{PC}}\right)$ and the carcasses were weighed to record the cold carcass weight (CCW).

The SW, EBW, HCW and CCW were used to determine the biological yield $[\mathrm{BY}=(\mathrm{HCW} / \mathrm{SW})$ $\mathrm{x} 100]$; the hot carcass yield $[\mathrm{HCY}=(\mathrm{HCW} / \mathrm{SW}) \mathrm{x}$ $100]$; the commercial or cold carcass yield $[\mathrm{CCY}=$ $(\mathrm{CCW} / \mathrm{SW}) \times 100]$ and cooling loss $[\mathrm{CL}=(\mathrm{HCW}-$ $\mathrm{CCW} / \mathrm{HCW} \times 100]$. 
The morphometry of the carcasses was evaluated based on the following measurements: carcass internal length (CIL) - measured with a measuring tape, corresponds to the distance from the front edge of the pubic bone to the cranial edge of the first rib; thoracic perimeter (TP) - using the bottom of the rib and the withers as basis, passing the measuring tape behind the shoulder; external leg length (ELL) - measured with a measuring tape in the lateral plane, corresponding to the distance between the base of the tail and the midpoint of the tarsal joint bones; internal leg length (ILL) - measured with measuring tape in the medial plane, corresponding to the distance between the front edge of the pubic bone and the midpoint of the tarsal joint bones; backfat thickness $\left(\mathrm{BFT}_{\mathrm{CARC}}\right)$ taken on the external face of the L. lumborum muscle between the $12^{\text {th }}$ and $13^{\text {th }}$ thoracic vertebrae, using a digital caliper. The carcass compactness index (CCI) was calculated by the relation between CCW and CIL $\left(\mathrm{kg} \mathrm{cm}^{-1}\right)$.

The carcasses were cut in the caudal-cranial direction into two halves, with the left half sectioned into seven commercial cuts as described by Colomer-Rocher and Espejo (1972): shoulder, leg, loin, uncovered ribs, true ribs, breast + flank and neck. In the dorsal portion of the L. lumborum muscle in the loin, by the cutoff point between the $13^{\text {th }}$ thoracic vertebra and the $1^{\text {st }}$ lumbar vertebra were measured the minimum and maximum thickness of fat on the ribeye (measure $\mathrm{C}$ and $\mathrm{J}$, respectively). The transverse profile of the $L$. lumborum muscle was drawn on tracing paper to get the ribeye area $\left(\mathrm{REA}_{\mathrm{LOIN}}\right)$, which was calculated by the ratio of the weight of the paper with a known area $\left(4 \mathrm{~cm}^{2}\right)$ and the weight of the paper where the ribeye profile was traced. The backfat thickness on the loin $\left(\mathrm{BFT}_{\text {LOIN }}\right)$ was obtained by averaging the measurements $\mathrm{C}$ and $\mathrm{J}$.

Meat quality analyses were carried out in food analysis laboratories at the Pontifícia Universidade Católica do Paraná (PUC-PR), Campus São José dos Pinhais located in São José dos Pinhais, Paraná State. Loin samples were frozen at $-18{ }^{\circ} \mathrm{C}$ for 90 days and later thawed to $5^{\circ} \mathrm{C}$ for $24 \mathrm{~h}$ to determine the physical and chemical parameters of the meat which included $\mathrm{pH}$, color, thawing loss (TL), water holding capacity (WHC) in raw samples; cooking loss (CKL) and shear force (SF) in cooked samples. Except for TL and WHC, these parameters were measured after thawing as described by Costa et al. (2011).

The $\mathrm{pH}$ measurement $\left(\mathrm{pH}_{\text {MEAT }}\right)$ was taken with a Jenway potentiometer (model 3020), calibrated to $\mathrm{pH} 4.0$ and 7.0. The meat color was assessed on the surface of each sample with a colorimeter Minolta Chroma Meter (CR-200) calibrated to a standard white in the CIELab system, where the coordinates of brightness $\left(\mathrm{L}^{*}\right)$, red coloration $\left(\mathrm{a}^{*}\right)$, yellow coloration $\left(\mathrm{b}^{*}\right)$, saturation $\left(\mathrm{C}^{*}\right)$ and hue $\left(\mathrm{H}^{*}\right)$ were measured. To determine the TL, the loin samples were thawed under refrigeration until reaching the internal temperature of 2 to $5^{\circ} \mathrm{C}$. TL was calculated by the difference between the weight of samples before and after thawing, being expressed in percentage basis. The WHC was determined by approximately $2.0 \mathrm{~g}$ sample of each loin in triplicate following the methodology proposed by Hamm (1960). The samples were weighed and packed between two filter papers and acrylic plates, and received a pressure exerted by a weight of $10 \mathrm{~kg}$ for $5 \mathrm{~min}$. After this process, the samples were weighed again and the amount of water lost was calculated. The result was expressed in percentage of water exuded on the weight of the initial sample.

To determine the CKL and SF, 24 loin samples were boiled in a water bath inside a plastic container resistant to heat until reaching an internal temperature of $70{ }^{\circ} \mathrm{C}$ and were subsequently cooled. The CKL corresponded to the weight difference between the samples before and after cooking, expressed as percentage basis. For the SF evaluation, three to seven portions were removed in a cylindrical shape of $1.27 \mathrm{~cm}$ diameter of each sample that was used to determine CKL. These portions were sheared perpendicularly to the direction of muscle fibers in the texturometer coupled to Warner-Bratzler device TA-XT Plus model, which measures the sample SF in $\mathrm{kgf} \mathrm{cm}^{-2}$. 


\section{Statistical analysis}

Data were submitted to regression analysis (PROC REG) in which the level of inclusion of urea in the ration was considered the independent variable. Analyses were carried out to the second order, according to the model $\hat{\mathrm{Y}}_{\mathrm{ij}}=\mathrm{b}_{0}$ model $_{0}+\mathrm{b}_{1} \mathrm{Ai}_{1}$ $+\mathrm{b}_{2} \mathrm{Ai}_{2}+\mathrm{g}_{(\mathrm{i}, \mathrm{j})}+\mathrm{e}_{(\mathrm{i}, \mathrm{j})}$, where: $\hat{\mathrm{Y}}_{\mathrm{ij}}=$ value of dependent variable for $\mathrm{j}^{\text {th }}$ observation in the $\mathrm{i}^{\text {th }}$ level of urea; $b_{0}$ $=$ regression intercept; $\mathrm{Ai}=$ independent variable; $\mathrm{b}_{1}=$ linear regression coefficient for the dependent variable; $b_{2}=$ quadratic regression coefficient for the dependent variable; $g_{(i, j)}=$ regression deviations for the $j^{\text {th }}$ observation in the $i^{\text {th }}$ level of urea; $e_{(i, j)}$ ) random error for the $\mathrm{j}^{\text {th }}$ observation in the $\mathrm{i}^{\text {th }}$ level of urea.

Pearson correlation analyses (PROC CORR) were performed to correlate the carcass traits among themselves and with the weights and yields of noncarcass components; and correlating the meat quality traits among themselves. In these analyzes, the partial option was used to adjust the correlation coefficients to the fixed effect of urea levels in the ration.

Statistical analyzes were performed using the Statistical Analysis System, version 9.0 (SAS, 2002). The level of $5 \%$ significance was adopted for all analyzes.

\section{Results and Discussion}

The levels of urea in the ration did not affect the $(\mathrm{P}>0.05)$ quantitative traits of the lambs carcasses
(Table 2). The average values for SW, EBW, HCW and $\mathrm{CCW}$ were $37.86 ; 33.21 ; 17.42$ and $16.95 \mathrm{~kg}$; and for BY, HCY, CCY and CL were 52.37; 45.92; 44.67 and $2.72 \%$, respectively. Proper use of urea in ruminant feeding can promote the use of energy from carbohydrates and modify tissue deposition in carcasses (ALVES et al., 2014). Some studies have reported increased carcass weight when the protein level was raised, with linear increase until the inclusion of $1.4 \%$ of urea in the diet (MENDOZA JÚNIOR et al., 2007). However, as observed in this study (Table 2), some studies have shown that increasing the levels of urea in the diet do not affect the carcass traits of lambs (SOUZA et al., 2004b; VOLTOLINI et al., 2010). It is likely that these results are due to similar conditions for the development of the carcasses, in which the SW of the animals was similar in all diets assessed; and urea inclusion levels in diets being too low to cause any significant tissue changes in the carcasses.

The results for $\mathrm{EBW}, \mathrm{HCW}$ and $\mathrm{CCW}$ in relation to the urea levels are in agreement with previous studies, which evaluated the levels of urea in the diet up to $1.2 \%$ (SOUZA et al., 2004b) and $1.95 \%$ (MAGALHÃES et al., 2006), and the replacing of conventional urea by slow-release urea (ALVES et al., 2014). On the other hand, Canbolat and Karabulut (2010) observed increased CCW with increased energy, protein and urea levels $(0,6,12$ and $18 \mathrm{~g}$ animal $\left.^{-1} \mathrm{~d}^{-1}\right)$.

Table 2. Means and coefficients of variation (CV) for carcass traits of feedlot lambs fed rations with increasing levels of urea.

\begin{tabular}{|c|c|c|c|c|c|c|c|}
\hline \multirow{2}{*}{ Variable $^{\mathrm{I}}$} & \multicolumn{4}{|c|}{ Urea (\% DM) } & \multirow{2}{*}{$\begin{array}{l}\text { CV } \\
(\%)\end{array}$} & \multicolumn{2}{|c|}{$P$-value $\mathrm{II}$} \\
\hline & 0.0 & 0.5 & 1.0 & 1.5 & & $\mathrm{~L}$ & $\mathrm{Q}$ \\
\hline SW (kg) & 37.67 & 38.08 & 38.00 & 37.73 & 13.40 & 0.9869 & 0.8813 \\
\hline EBW $(\mathrm{kg})$ & 32.94 & 32.78 & 33.38 & 33.68 & 13.97 & 0.7532 & 0.9165 \\
\hline $\mathrm{HCW}(\mathrm{kg})$ & 17.43 & 17.05 & 17.56 & 17.59 & 15.49 & 0.8515 & 0.8750 \\
\hline CCW (kg) & 16.93 & 16.67 & 17.13 & 17.01 & 15.41 & 0.8936 & 0.9665 \\
\hline BY $(\%)$ & 52.87 & 51.78 & 52.54 & 52.19 & 3.44 & 0.6852 & 0.6749 \\
\hline $\operatorname{HCY}(\%)$ & 46.17 & 44.51 & 46.15 & 46.61 & 4.76 & 0.5083 & 0.2902 \\
\hline CCY (\%) & 44.83 & 43.54 & 45.03 & 45.09 & 4.76 & 0.6012 & 0.5072 \\
\hline CL (\%) & 2.94 & 2.18 & 2.44 & 3.22 & 43.27 & 0.6531 & 0.1292 \\
\hline
\end{tabular}

I SW: slaughter weight; EBW: empty body weight; HCW: hot carcass weight; CCW: cold carcass weight; BY: biological yield; HCY: hot carcass yield; CCY: cold carcass yield; CL: cooling losses

${ }^{\text {II }} \mathrm{L}$ : linear regression; Q: quadratic regression. 
The average value for BY was similar to that described by Souza et al. (2004b) (average 51.0\%) with addition of up to $1.2 \%$ of urea in the diet. Values lower than that obtained in this study were described by Ziguer et al. (2012) (average 47.2\%), which used soybean hulls associated with different sources of non-protein nitrogen (conventional urea, protected urea, protected urea + urea conventional).

Additional results of this study obtained by Vivian et al. (2017) indicated there was no significant effect $(\mathrm{P}>0.05)$ of urea levels on DM intake (DMI). The average DMI during the trial was $1.174 \mathrm{~kg}$ animal ${ }^{-1}$ $\mathrm{d}^{-1}$, and met the requirements for fast and moderate growth according to the NRC (1985) $(\mathrm{DMI}=1.0$ to $1.3 \mathrm{~kg} \mathrm{DM}_{\text {animal }}{ }^{-1} \mathrm{~d}^{-1}$ ). Thus, the urea levels in the diet did not affect the weight of DC and did not cause depletion of food intake by physical filling of the GIT, which are factors that affect directly the BY.

The mean values for HCY and CCY are in agreement with the literature $(46.0 \%$ and $44.5 \%$ respectively). The $\mathrm{CL}$ in sheep carcasses may vary between 1 and $7 \%$, usually found close to $2.5 \%$. This characteristic is influenced by the, sex, weight, fat covering of the carcass, temperature and humidity in the cold storage chamber, and the handling of the carcasses (MORENO et al., 2008). The muscle fiber composition is also of particular importance because muscles with predominance of red fibers are more susceptible to shortening by the cooling. This occurs due to red fibers have small ability to retain calcium and $\mathrm{pH}$ at low temperatures (ZEOLA et al., 2007). However, the muscle fibers are formed during pregnancy and only minor muscle fibers suffer from environmental interference, such as maternal nutrition (ZÜNDT et al., 2006). The CL values obtained in this study are close to the normal value observed in lamb carcasses, and are justified by similar deposition of fat in the carcass and its proper handling and storage immediately after slaughter.

The levels of urea did not affect $(\mathrm{P}>0.05)$ the morphometric traits (Table 3), with average values of $67.4 \mathrm{~cm}, 72.3 \mathrm{~cm}, 45.1 \mathrm{~cm} ; 36.3 \mathrm{~cm}$ and $0.255 \mathrm{~kg}$ $\mathrm{cm}^{-1}$ for CIL, TP, ELL, ILL and CCI, respectively. These traits are in agreement with previous studies that reported that the carcass morphometry is not influenced by its food system, as long as the animals are slaughtered in the same weight range (ALVES et al., 2014). The average CCI obtained in this study $\left(0.255 \mathrm{~kg} \mathrm{~cm}^{-1}\right)$ was similar to that described by Souza et al. (2004b), who used up to $1.2 \%$ of urea in the diet of the lambs.

Table 3. Means and coefficient of variation (CV) for the morphometric measurements of the carcasses of feedlot lambs fed rations with increasing levels of urea.

\begin{tabular}{|c|c|c|c|c|c|c|c|}
\hline \multirow{2}{*}{ Variable $^{I}$} & \multicolumn{4}{|c|}{ Urea (\% DM) } & \multirow{2}{*}{$\begin{array}{l}\text { CV } \\
(\%)\end{array}$} & \multicolumn{2}{|c|}{$P$-value ${ }^{\mathrm{II}}$} \\
\hline & 0.0 & 0.5 & 1.0 & 1.5 & & $\mathrm{~L}$ & Q \\
\hline CIL $(\mathrm{cm})$ & 66.2 & 69.0 & 67.3 & 67.7 & 3.68 & 0.4672 & 0.3411 \\
\hline $\mathrm{TP}(\mathrm{cm})$ & 70.8 & 72.3 & 73.3 & 72.9 & 5.05 & 0.2877 & 0.5502 \\
\hline ELL (cm) & 44.5 & 45.4 & 44.7 & 45.8 & 6.52 & 0.5467 & 0.8879 \\
\hline ILL (cm) & 35.3 & 36.9 & 36.1 & 37.1 & 5.82 & 0.2517 & 0.7882 \\
\hline $\mathrm{CCI}\left(\mathrm{kg} \mathrm{cm}^{-1}\right)$ & 0.255 & 0.261 & 0.255 & 0.251 & 12.32 & 0.7773 & 0.7684 \\
\hline
\end{tabular}

I CIL: carcass internal length; TP: thoracic perimeter; ELL: external leg length; ILL: internal leg length; CCI: carcass compactness index

${ }^{\text {II }} \mathrm{L}$ : linear regression; Q: quadratic regression. 
The backfat thickness and ribeye area that were measured in vivo by ultrasound, in the carcass right after the slaughter and in the L. lumborum muscle were not affected $(\mathrm{P}>0.05)$ by urea levels in the ration (Table 4). It was recorded mean values of
8.99 and $10.40 \mathrm{~cm}^{2}$ for initial and final $\mathrm{REA}_{\mathrm{US}} ; 3.63$ and $5.30 \mathrm{~mm}$ for initial and final $\mathrm{BFT}_{\mathrm{US}} ; 2.52 \mathrm{~mm}$ for $\mathrm{BFT}_{\mathrm{CARC}} ; 14.26 \mathrm{~cm}^{2}$ and $3.61 \mathrm{~mm}$ for $\mathrm{REA}_{\text {LOIN }}$ and $\mathrm{BFT}_{\mathrm{LOIN}}$, respectively.

Table 4. Means and coefficient of variation (CV) for ribeye area (REA) and backfat thickness (BFT) measured in vivo by ultrasonography, directly in the carcass and in the Longissimus lumborum muscle of feedlot lambs fed ration with increasing levels of urea.

\begin{tabular}{|c|c|c|c|c|c|c|c|}
\hline \multirow{2}{*}{ Variable $^{\mathrm{I}}$} & \multicolumn{4}{|c|}{ Urea (\% DM) } & \multirow{2}{*}{$\begin{array}{l}\text { CV } \\
(\%)\end{array}$} & \multicolumn{2}{|c|}{$P$-value ${ }^{\mathrm{II}}$} \\
\hline & 0.0 & 0.5 & 1.0 & 1.5 & & $\mathrm{~L}$ & Q \\
\hline Initial REA $\mathrm{US}_{\mathrm{US}}\left(\mathrm{cm}^{2}\right)$ & 9.79 & 8.92 & 8.22 & 9.01 & 18.04 & 0.3141 & 0.2181 \\
\hline Final $\operatorname{REA}_{\mathrm{US}}\left(\mathrm{cm}^{2}\right)$ & 11.04 & 10.51 & 10.20 & 10.08 & 13.65 & 0.3064 & 0.7738 \\
\hline Initial $\mathrm{BFT}_{\mathrm{US}}(\mathrm{mm})$ & 3.87 & 3.54 & 3.48 & 3.60 & 14.57 & 0.3768 & 0.3320 \\
\hline Final $\mathrm{BFT}_{\mathrm{US}}(\mathrm{mm})$ & 5.72 & 4.72 & 5.56 & 5.17 & 17.83 & 0.5915 & 0.4782 \\
\hline $\mathrm{BFT}_{\mathrm{CARC}}(\mathrm{mm})$ & 2.44 & 2.26 & 2.82 & 2.56 & 28.51 & 0.5391 & 0.8842 \\
\hline $\operatorname{REA}_{\text {LOIN }}\left(\mathrm{cm}^{2}\right)$ & 14.60 & 13.25 & 14.09 & 14.95 & 16.53 & 0.6940 & 0.2945 \\
\hline $\mathrm{BFT}_{\text {IOIN }}(\mathrm{mm})$ & 3.64 & 3.43 & 3.59 & 3.77 & 25.02 & 0.7381 & 0.6382 \\
\hline
\end{tabular}

${ }^{\mathrm{I}} \mathrm{REA}_{\mathrm{US}}$ : ribeye area measured by ultrasonography; $\mathrm{BFT}_{\mathrm{US}}$ : backfat thickness measured by ultrasonography; BFT ${ }_{\mathrm{CARC}}$ : backfat thickness measured in the carcass; REA $_{\text {LoIN }}$ : ribeye area measured in the Longissimus lumborum muscle; BFT $_{\text {LoIN }}$ : backfat thickness measured in the Longissimus lumborum muscle

${ }^{\text {II }} \mathrm{L}$ : linear regression; Q: quadratic regression.

Fat is the largest carcass component variation, increasing with age and weight at slaughter (MACEDO et al., 2000). This can be seen in the values obtained by ultrasound, in which the fat thickness on the REA increased during the trial regardless of urea levels in the ration (mean for initial $\mathrm{BFT}_{\mathrm{US}}=3.63 \mathrm{~mm}$; mean for final $\mathrm{BFT}_{\mathrm{US}}=$ $5.30 \mathrm{~mm}$; Table 4). REA was not influenced by urea levels in the ration, but increased during the trial as was indicated by measurements made by ultrasound (mean for initial REA $\mathrm{US}_{\mathrm{US}}=8.99 \mathrm{~cm}^{2}$, mean for final $\mathrm{REA}_{\mathrm{US}}=10.40 \mathrm{~cm}^{2}$; Table 4).

The carcass evaluation made by ultrasound preslaughter resulted in higher values of fat thickness and a smaller REA compared to those done in the carcass (mean for $\mathrm{BFT}_{\mathrm{CARC}}=2.52 \mathrm{~mm}$ ) and loin (mean of $3.61 \mathrm{~mm}$ for $\mathrm{BFT}_{\text {LoIN }}$; mean of 14.26 $\mathrm{cm}^{2}$ for $\mathrm{REA}_{\text {LoIN }}$; Table 4). This was also reported by Ítavo et al. (2009), which suggested that the existence of wool, the softness of the fat and the mobility of the skin may be the reasons for the lower accuracy of the measurements performed by ultrasound. Nevertheless, the final REA ${ }_{U S}$ showed moderate and positive correlation with $\mathrm{REA}_{\text {LOIN }}(\mathrm{r}=$ $0.69 ; \mathrm{P}=0.0008)$ and $\mathrm{BFT}_{\text {LoIN }}(\mathrm{r}=0.50 ; \mathrm{P}=0.0245)$, while the final $\mathrm{BFT}_{\mathrm{US}}$ showed no correlation $(\mathrm{P}>$ 0.05 ) with the measurements in the carcass and in the loin. Thus, even with low accuracy, the REA measured by ultrasound in pre-slaughter can be an indicator of muscle development and fattening degree of lamb carcasses.

A minimum fat cover is needed to protect the carcass from water loss and cold burns during cooling and freezing, and to keep the organoleptic characteristics of the meat (SANTOS et al., 2009). The average fat thickness covering the carcasses which was obtained in this study $\left(\mathrm{BFT}_{\mathrm{CARC}}=2.52\right.$ $\mathrm{mm}$ ) was higher than that reported by Ítavo et al. (2009). The mean value for REA measured in the loin $\left(\mathrm{REA}_{\text {LOIN }}=14.26 \mathrm{~cm}^{2}\right)$ was close to that reported by Urano et al. (2006), who observed a REA of 14.8 $\mathrm{cm}^{2}$ in lambs slaughtered at $37.7 \mathrm{~kg} \mathrm{BW}$. These 
results indicate that the SW and the feedlot period were enough to produce standardized and welldeveloped carcasses and, with no influence of urea levels in the diet on the deposition of covering fat.

The weight of the commercial cuts were not affected $(\mathrm{P}>0.05)$ by urea levels in the ration (Table 5 ). The mean values for weight of neck, uncovered ribs, true ribs, breast + flank, loin, shoulder and leg were $0.719 ; 0.503 ; 0.949 ; 1.110 ; 0.924 ; 1.562$ and $2.784 \mathrm{~kg}$, respectively.

For the yield of cuts, there was a quadratic effect of urea levels $(\mathrm{P}<0.05)$ on the loin yield, which was higher in lambs that received ration with $1 \% \mathrm{DM}$ urea (Table 5). This can be explained by the increase of CP in the diet promoted by this level of inclusion of urea. The regression equation indicates that the maximum loin yield (11.31\%) can be obtained by including $0.84 \%$ DM urea in the ration. This is interesting from an economic point of view, since it is possible to increase the yield of a highly valuable commercial prime cut by supplying a cheaper ration for the lambs. Other studies showed no effect of urea levels in the diet on the loin yield, and on the weight and yield of other commercial cuts of the lamb carcass (SOUZA et al., 2004b; VOLTOLINI et al., 2010).

The mean values of yield of neck, uncovered ribs, true ribs, breast + flank, loin, shoulder and leg were $8.35 ; 5.83 ; 11.05 ; 12.95 ; 10.84 ; 18.30$ and $32.68 \%$, respectively. It is noteworthy that the yield of loin, shoulder and leg, which are the prime cuts of higher commercial value, accounted for $61.83 \%$ of the lambs carcass. From these cuts, leg showed greater weight (mean of $2.784 \mathrm{~kg}$ ) and higher yield (mean of $32.70 \%$ ), which confirms that the leg is the noblest cut of the carcass because of the greater amount of muscle mass and, consequently, the higher meat yield (RIBEIRO et al., 2009).

Table 5. Means and coefficient of variation $(\mathrm{CV})$ for weight and yield of carcass cuts of feedlot lambs fed rations with increasing levels of urea.

\begin{tabular}{|c|c|c|c|c|c|c|c|}
\hline \multirow{2}{*}{ Variable $^{\mathrm{I}}$} & \multicolumn{4}{|c|}{ Urea (\% DM) } & \multirow{2}{*}{$\begin{array}{l}\mathrm{CV} \\
(\%)\end{array}$} & \multicolumn{2}{|c|}{$P$-value II } \\
\hline & 0.0 & 0.5 & 1.0 & 1.5 & & $\mathrm{~L}$ & Q \\
\hline \multicolumn{8}{|l|}{ Weight (kg) } \\
\hline Neck & 0.718 & 0.682 & 0.710 & 0.760 & 26.74 & 0.6846 & 0.6150 \\
\hline $\operatorname{Ribs}_{\mathrm{UNCOV}}$ & 0.518 & 0.482 & 0.485 & 0.522 & 24.90 & 0.9608 & 0.5090 \\
\hline Ribs $_{\text {TRUE }}$ & 0.941 & 0.924 & 0.974 & 0.951 & 19.74 & 0.8272 & 0.9543 \\
\hline $\mathrm{BF}$ & 1.138 & 1.062 & 1.071 & 1.163 & 18.61 & 0.8472 & 0.3506 \\
\hline Loin & 0.884 & 0.931 & 0.958 & 0.925 & 14.67 & 0.5497 & 0.4947 \\
\hline Shoulder & 1.567 & 1.540 & 1.568 & 1.571 & 15.91 & 0.9360 & 0.8970 \\
\hline Leg & 2.849 & 2.776 & 2.753 & 2.756 & 14.76 & 0.6950 & 0.8340 \\
\hline \multicolumn{8}{|l|}{ Yield (\%) } \\
\hline Neck & 8.31 & 8.08 & 8.30 & 8.66 & 16.28 & 0.6302 & 0.6306 \\
\hline $\operatorname{Ribs}_{\mathrm{UNCOV}}$ & 5.92 & 5.73 & 5.65 & 6.00 & 14.39 & 0.9269 & 0.4562 \\
\hline Ribs $_{\text {TRUE }}$ & 10.86 & 10.95 & 11.41 & 10.95 & 8.02 & 0.6655 & 0.4413 \\
\hline $\mathrm{BF}$ & 13.22 & 12.58 & 12.55 & 13.41 & 7.36 & 0.7827 & 0.0623 \\
\hline Loin III & 10.31 & 11.18 & 11.24 & 10.70 & 6.71 & 0.3396 & 0.0167 \\
\hline Shoulder & 18.19 & 18.39 & 18.44 & 18.20 & 5.50 & 0.9537 & 0.6142 \\
\hline Leg & 33.21 & 33.10 & 32.41 & 32.09 & 6.39 & 0.3054 & 0.9206 \\
\hline
\end{tabular}

${ }^{\mathrm{I}}$ Ribs $_{\mathrm{UNCOV}}$ : uncovered ribs; Ribs $\mathrm{TRUE}_{\mathrm{E}}$ : true ribs; BF: breast + flank

${ }^{\mathrm{II}} \mathrm{L}$ : linear regression; Q: quadratic regression

${ }^{\text {III }} \mathrm{Y}_{\text {LOIN }}=-1.4042 \mathrm{U}^{2}+2.3547 \mathrm{U}+10.3186\left(\mathrm{R}^{2}=0.9972\right)$. 
There was no significant effect $(\mathrm{P}>0.05)$ of urea levels on the weight of head, paws, skin, red viscera and fatty deposits (Table 6). The mean values for weight of head, paws, skin, blood and adipose deposits were $2.177 ; 0.918 ; 4.371 ; 1.934$ and $0.929 \mathrm{~kg}$, respectively. The mean values for weight of heart, lungs, liver, spleen and kidneys, which are characterized as red viscera, were 0.160 ; $0.660 ; 0.859 ; 0.171$ and $0.132 \mathrm{~kg}$, respectively. When the organ weights are uniform and have an earlier maturation, they are less affected by dietary treatment in a later stage of life (FASAE et al., 2011). Heart (mean of $0.160 \mathrm{~kg}$ ) and lungs (mean of $0.660 \mathrm{~kg}$ ) weights are in agreement with other studies (MORENO et al., 2011), demonstrating that these organs maintain the integrity and have priority in the use of nutrients, regardless of their diet. The lack of effect of urea levels on adipose deposits was also reported in other studies evaluating the weight of non-carcass component in lambs receiving up to $1.4 \%$ urea in the diet (MEDEIROS et al., 2011).

High weight of some non-carcass components such as head, skin and blood can adversely affect the carcass yield (LANDIM et al., 2007), which did not occur in this study. In fact, the head, paws and skin weights, the assembly formed by these three components (HPS) and the blood weight showed no correlation $(\mathrm{P}>0.05)$ with BY, HCY and CCY, which confirms that these components did not affected the carcass yield of the lambs.

Except for the yield of rumen + reticulum in relation to the empty body weight $\left(\mathrm{RR}_{\mathrm{EBW}}\right)$, there was no effect $(\mathrm{P}>0.05)$ of the urea levels in the ration on weight and yield of GIT and its organs, and also on the DC (Table 7).

Table 6. Means and coefficient of variation (CV) for weight of head, paws, skin, blood, red viscera and fatty deposits of feedlot lambs fed rations with increasing levels of urea.

\begin{tabular}{|c|c|c|c|c|c|c|c|}
\hline \multirow{2}{*}{ Variable $^{\mathrm{I}}$} & \multicolumn{4}{|c|}{ Urea (\% DM) } & \multirow{2}{*}{$\begin{array}{l}\mathrm{CV} \\
(\%)\end{array}$} & \multicolumn{2}{|c|}{$P$-value II } \\
\hline & 0.0 & 0.5 & 1.0 & 1.5 & & $\mathrm{~L}$ & $\mathrm{Q}$ \\
\hline Head (kg) & 1.973 & 2.219 & 2.223 & 2.267 & 13.61 & 0.1290 & 0.4449 \\
\hline Paws (kg) & 0.871 & 0.904 & 0.925 & 0.968 & 14.48 & 0.2047 & 0.9279 \\
\hline Skin $(k g)$ & 4.016 & 4.785 & 4.167 & 4.584 & 15.45 & 0.3591 & 0.6266 \\
\hline HPS (kg) & 7.021 & - 7.908 & 7.315 & 7.819 & 11.54 & 0.2967. & 0.7052 \\
\hline Blood $(\mathrm{kg})$ & $\overline{1} . \overline{83} \overline{3}$ & $\overline{1.768}$ & $\overline{2} . \overline{17} \overline{4}$ & $\overline{1.935}$ & $\overline{3} 2 . \overline{7}$ & $0 . \overline{5642}$ & $0 . \overline{71} \overline{125}$ \\
\hline Heart (kg) & 0.157 & 0.158 & 0.165 & 0.159 & 14.25 & 0.7726 & 0.7218 \\
\hline Lungs (kg) & 0.626 & 0.634 & 0.689 & 0.687 & 17.85 & 0.2839 & 0.8995 \\
\hline Liver (kg) & 0.891 & 0.843 & 0.792 & 0.909 & 18.64 & 0.9944 & 0.2218 \\
\hline Spleen $(\mathrm{kg})$ & 0.184 & 0.162 & 0.171 & 0.167 & 27.64 & 0.6267 & 0.6920 \\
\hline Kidneys (kg) & 0.128 & 0.135 & 0.139 & 0.125 & 15.52 & 0.9047 & 0.2570 \\
\hline Red viscera $(\mathrm{kg})$ & 1.985 & 1.931 & 1.955 & 2.047 & 14.59 & 0.7114 & 0.5646 \\
\hline Fatty deposits $(\mathrm{kg})$ & $\overline{0} . \overline{8} 1 \overline{2}$ & $\overline{0} . \overline{850}$ & $\overline{1.040}$ & $\overline{0} . \overline{9} 8 \overline{1}$ & $\overline{4} 2.1 \overline{6}$ & $0.3 \overline{7} \overline{28}$ & $0 . \overline{75} \overline{11}$ \\
\hline
\end{tabular}

${ }^{\mathrm{I}} \mathrm{HPS}$ : sum of head, paws and skin weights; Red Viscera: sum of heart, lungs, liver, spleen and kidneys weights; Adipose Deposits: sum of omental, mesenteric and perirenal fat weights

${ }^{\text {II }}$ L: linear regression; Q: quadratic regression. 
Table 7. Means and coefficients of variation (CV) for weights of gastrointestinal tract (GIT), digestive content (DC) and organs from GIT and their yields relative to GIT and to the empty body weight (EBW) of feedlot lambs fed rations with increasing levels of urea.

\begin{tabular}{|c|c|c|c|c|c|c|c|}
\hline \multirow{2}{*}{ Variable $^{\mathrm{I}}$} & \multicolumn{4}{|c|}{ Urea (\% DM) } & \multirow{2}{*}{$\begin{array}{l}\text { CV } \\
(\%)\end{array}$} & \multicolumn{2}{|c|}{$P$-value ${ }^{\text {II }}$} \\
\hline & 0.0 & 0.5 & 1.0 & 1.5 & & $\mathrm{~L}$ & $\mathrm{Q}$ \\
\hline Full GIT (kg) & 7.257 & 8.138 & 7.428 & 6.840 & 14.73 & 0.3657 & 0.1212 \\
\hline $\mathrm{DC}(\mathrm{kg})$ & 4.724 & 5.297 & 4.622 & 4.053 & 20.54 & 0.1403 & 0.1582 \\
\hline Empty GIT (kg) & 2.533 & 2.840 & 2.806 & 2.787 & 14.75 & 0.3201 & 0.3591 \\
\hline $\mathrm{RR}(\mathrm{kg})$ & 0.763 & 0.884 & 0.874 & 0.847 & 12.56 & 0.2019 & 0.0935 \\
\hline Omasum (kg) & 0.095 & 0.120 & 0.096 & 0.100 & 21.74 & 0.9302 & 0.3407 \\
\hline Abomasum (kg) & 0.234 & 0.219 & 0.225 & 0.228 & 19.57 & 0.8721 & 0.6484 \\
\hline Intestine (kg) & 1.441 & 1.618 & 1.611 & 1.612 & 20.38 & 0.3878 & 0.5373 \\
\hline $\mathrm{RR}_{\mathrm{GIT}}(\%)$ & 30.23 & 31.37 & 31.51 & 30.71 & 10.58 & 0.7882 & 0.4991 \\
\hline Omasum $_{\mathrm{GIT}}(\%)$ & 3.73 & 4.22 & 3.45 & 3.60 & 16.71 & 0.3579 & 0.6083 \\
\hline Abomasum $_{\mathrm{GIT}}(\%)$ & 9.29 & 7.83 & 8.10 & 8.18 & 18.98 & 0.2841 & 0.2701 \\
\hline Intestine $_{\mathrm{GIT}}(\%)$ & 56.75 & 56.58 & 56.94 & 57.52 & 7.42 & 0.7441 & 0.8434 \\
\hline $\mathrm{RR}_{\mathrm{EBW}}(\%)^{\mathrm{III}}$ & 2.35 & 2.71 & 2.64 & 2.53 & 11.32 & 0.3606 & 0.0483 \\
\hline Omasum $_{\mathrm{EBW}}(\%)$ & 0.29 & 0.37 & 0.29 & 0.30 & 19.50 & 0.6385 & 0.2009 \\
\hline Abomasum $_{\mathrm{EBW}}(\%)$ & 0.72 & 0.67 & 0.69 & 0.68 & 21.19 & 0.6710 & 0.7110 \\
\hline Intestine $_{\mathrm{EBW}}(\%)$ & 4.44 & 4.97 & 4.84 & 4.77 & 16.97 & 0.5476 & 0.4027 \\
\hline $\operatorname{GIT}_{\mathrm{EBW}}(\%)$ & 7.80 & 8.72 & 8.46 & 8.27 & 11.77 & 0.5007 & 0.1980 \\
\hline
\end{tabular}

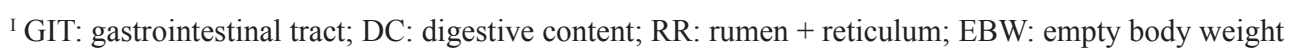

${ }^{\text {II }} \mathrm{L}$ : linear regression; $\mathrm{Q}$ : quadratic regression

${ }^{\text {III }} \mathrm{RR}_{\mathrm{EBW}}=-0.4713 \mathrm{U}^{2}+0.8020 \mathrm{U}+2.3645\left(\mathrm{R}^{2}=0.9009\right)$.

There was a quadratic effect $(\mathrm{P}<0.05)$ of urea levels on $\mathrm{RR}_{\mathrm{EBW}}$, which was higher $(2.71 \%)$ in lambs that received ration with $0.5 \% \mathrm{DM}$ of urea (Table 7). Under the conditions of this study, the regression equation indicated that the inclusion of $0.85 \% \mathrm{DM}$ of urea in the ration allows achieving the maximum value of $\mathrm{RR}_{\mathrm{EBW}}$, which corresponds to $2.71 \%$ and is similar to the value found for the inclusion of $0.5 \%$ $\mathrm{DM}$ of urea in the ration. Thus, the maximum yield of rumen + reticulum can be achieved by providing diets containing 0.5 to $0.85 \% \mathrm{DM}$ of urea to the lambs.

The increase in the forage:concentrate ratio $(\mathrm{F}: \mathrm{C})$ in the diet, which leads to increased fiber content and lower energy content in its composition, leads to increased size of the rumen, reticulum and omasum (REIS; SILVA, 2006). Although the rations were isoproteic (17.03\% DM of CP on average), the F:C and the neutral detergent fiber (NDF) content varied among the experimental diets (Table 1). The F:C ratio ranged from 25:75 to 40:60 and the NDF content ranged from 28.55 to $56.63 \%$, where the rations with 0.5 and $1.0 \%$ DM of urea showed higher NDF (44.75 and $56.63 \%$, respectively). The high NDF on these diets is associated with the greater inclusion of soybean hulls in their compositions with inclusion of 25 and $49 \%$ DM, respectively. In assessing the nutrient intake by lambs of this study, Vivian et al. (2017) observed a quadratic effect of urea levels on NDF intake, which reached a maximum value $\left(0.665 \mathrm{~kg} \mathrm{DM} \mathrm{d}^{-1}\right)$ in the ration with $1.0 \% \mathrm{DM}$ of urea. However, the regression equation indicates that the maximum NDF intake $\left(0.604 \mathrm{~kg} \mathrm{DM} \mathrm{d}^{-1}\right)$ may be achieved with the inclusion of $0.85 \% \mathrm{DM}$ of urea in the ration. This justifies the possibility of obtaining the maximum $\mathrm{RR}_{\mathrm{EBW}}(2.71 \%)$ when the ration containing the same inclusion of urea is provided to the lambs. These results show that the type of food and the $\mathrm{F}: \mathrm{C}$ ratio of the diet has great influence on the non-carcass components, especially those involved in the digestion and absorption of nutrients. 
Although they were not influenced $(\mathrm{P}>0.05)$ by urea levels, the $\mathrm{pH}_{\mathrm{PS}}$ values were higher in the carcasses of lambs that received rations without urea (6.68) and with $0.5 \%$ DM of urea (6.83); and $\mathrm{pH}_{\mathrm{PC}}$ value was higher in the carcasses of lambs fed diets with $0.5 \% \mathrm{DM}$ of urea (6.05; Table 8$)$. The normal values for sheep meat range from 7.3 to 7.5 at slaughter, resulting in a final value of 5.5 to 5.8 between 12 to $24 \mathrm{~h}$ after slaughter (ZEOLA et al., 2007).

The carcass $\mathrm{pH}$ can be influenced by the SW and the BFT (CEZAR; SOUSA, 2007). The $\mathrm{pH}_{\mathrm{PS}}$ and $\mathrm{pH}_{\mathrm{PC}}$ showed no correlation $(\mathrm{P}>0.05)$ with the SW and the BFT measured by ultrasound in the preslaughter (final $\left.\mathrm{BFT}_{\mathrm{US}}\right)$, in the carcass $\left(\mathrm{BFT}_{\mathrm{CARC}}\right)$ and loin $\left(\mathrm{BFT}_{\mathrm{LOIN}}\right)$, which indicates that these traits did not affect the carcass $\mathrm{pH}$ of the lambs. The greater supply of protein in the diet, which affects muscle chemical composition, may determinate high $\mathrm{pH}$ in the carcass (OSÓRIO et al., 2009). The diets used in this study were isoproteic, however, it was expected that the increasing levels of urea could change the $\mathrm{pH}_{\mathrm{PS}}$ and $\mathrm{pH}_{\mathrm{PC}}$, which was not proved (Table 8).

Although the $\mathrm{pH}_{\text {MEAT }}$ is within the normal range (5.5 to 5.8), it showed a quadratic response to urea levels in the ration (Table 8). The lowest $\mathrm{pH}$ values were recorded in the meat of lambs that received rations with 0.5 and $1.0 \% \mathrm{DM}$ of urea (5.55), and the highest in the lambs fed ration with $1.5 \% \mathrm{DM}$ of urea (5.68). The regression equation indicates that the minimum value for $\mathrm{pH}_{\text {MEAT }}$ (5.53) can be obtained by including $0.53 \%$ DM of urea in the diet.
Gluconeogenesis and ureogenesis are vital for the metabolism of ruminants. However, ammonia affects the gluconeogenesis, reducing the conversion of propionate to glucose. This mechanism is still not well described, but significant effects have been detected suggesting a specific response of ammonia in the competition for energy (ATP) required for synthesis of glucose or urea (NORO et al., 2012). The small glycogen reserve causes the decrease of glucose levels in the muscles, which determines lower production of lactic acid by anaerobiosis and hence little decrease in pH (ZEOLA et al., 2007). Probably the darkest meat from lambs fed ration with $1.5 \% \mathrm{DM}$ of urea can be associated with the highest concentration of ammonia in the muscle, which may have interfered in gluconeogenesis, reducing the availability of glucose to the formation of glycogen reserves in the muscles. This determined the highest $\mathrm{pH}$ in the meat $\left(\mathrm{pH}_{\text {MEAT }}=5.68\right)$ of lambs receiving $1.5 \%$ of DM urea in the ration (Table 8 ).

The $\mathrm{pH}$ is directly related to other meat quality traits, which was confirmed by the moderate to high correlations of $\mathrm{pH}_{\text {MEAT }}$ with coordinates $\mathrm{L}^{*}, \mathrm{a}^{*}$ and $C^{*}$. The sheep meat usually has values from 30.03 to 49.47 for $\mathrm{L}^{*} ; 8.24$ to 23.53 for $\mathrm{a}^{*}$ and from 3.38 to 11.10 for $b^{*}$ (SOUZA et al., 2004a). Thus, the values found in this study (Table 8) are close to those described in the literature.

There was a quadratic effect $(\mathrm{P}<0.05)$ of urea levels on the color coordinates $\mathrm{L}^{*}, \mathrm{a}^{*}$ and $\mathrm{C}^{*}$ (Table $8)$. The $b^{*}$ and $H^{*}$ coordinates were not $(\mathrm{P}>0.05)$ influenced by urea levels and showed mean values of 8.30 and 28.71 , respectively. 
Table 8. Means and coefficients of variation (CV) for carcass $\mathrm{pH}$ and meat quality traits of feedlot lambs fed rations with increasing levels of urea.

\begin{tabular}{|c|c|c|c|c|c|c|c|}
\hline \multirow{2}{*}{ Variable $^{\mathrm{I}}$} & \multicolumn{4}{|c|}{ Urea (\% DM) } & \multirow{2}{*}{$\begin{array}{l}\text { CV } \\
(\%)\end{array}$} & \multicolumn{2}{|c|}{$P$-value ${ }^{\mathrm{II}}$} \\
\hline & 0.0 & 0.5 & 1.0 & 1.5 & & $\mathrm{~L}$ & Q \\
\hline $\mathrm{pH}_{\mathrm{PS}}$ & 6.68 & 6.83 & 6.46 & 6.56 & 4.31 & 0.1854 & 0.8975 \\
\hline $\mathrm{pH}_{\mathrm{PC}}$ & 5.80 & 6.05 & 5.86 & 5.83 & 5.75 & 0.9274 & 0.3729 \\
\hline TL $(\%)$ & 2.93 & 2.18 & 2.08 & 2.30 & 63.48 & 0.4749 & 0.4629 \\
\hline WHC (\%) & 34.16 & 35.24 & 34.21 & 34.50 & 8.68 & 0.9867 & 0.7921 \\
\hline $\mathrm{pH}_{\text {MEAT }}{ }^{\text {III }}$ & 5.57 & 5.56 & 5.55 & 5.68 & 1.56 & 0.0485 & 0.0291 \\
\hline CKL $(\%)$ & 25.27 & 24.98 & 23.75 & 24.22 & 13.91 & 0.5003 & 0.7823 \\
\hline 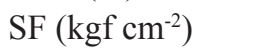 & 2.81 & 2.86 & 3.01 & 2.58 & 21.52 & 0.6450 & 0.3537 \\
\hline \multicolumn{8}{|l|}{ Colour coordinates } \\
\hline $\mathrm{L}^{* \mathrm{III}}$ & 46.50 & 48.96 & 47.03 & 42.53 & 8.81 & 0.0689 & 0.0269 \\
\hline$a^{*}$ III & 15.48 & 14.43 & 14.17 & 16.52 & 10.07 & 0.3375 & 0.0040 \\
\hline $\mathrm{b}^{*}$ & 8.77 & 8.37 & 7.87 & 8.20 & 14.09 & 0.3148 & 0.4465 \\
\hline $\mathrm{C}^{*} \mathrm{III}$ & 17.84 & 16.70 & 16.23 & 18.52 & 9.18 & 0.6284 & 0.0065 \\
\hline $\mathrm{H}^{*}$ & 29.44 & 30.13 & 28.94 & 26.58 & 12.22 & 0.1378 & 0.2962 \\
\hline
\end{tabular}

${ }^{\mathrm{I}} \mathrm{pH}_{\mathrm{PS}}: \mathrm{pH}$ of carcass post-slaughter; $\mathrm{pH}_{\mathrm{PC}}$ : $\mathrm{pH}$ of carcass post-cooling; TL: thawing loss; WHC: water holding capacity; $\mathrm{pH}_{\mathrm{MEAT}}$ : $\mathrm{pH}$ of the meat; CKL: cooking loss; SF: shear force; L*: brightness; $\mathrm{a}^{*}$ : intensity of red colour; $\mathrm{b}^{*}$ : intensity of yellow colour; $\mathrm{C}^{*}$ : colour saturation; $\mathrm{H}^{*}$ : colour tone of the meat

${ }^{\text {II }} \mathrm{L}$ : linear regression; Q: quadratic regression

III $\mathrm{pH}_{\text {MEAT }}=0.1442 \mathrm{U}^{2}-0.1529 \mathrm{U}+5.5749\left(\mathrm{R}^{2}=0.9405\right)$

$\mathrm{L}^{*}=-6.9145 \mathrm{U}^{2}+7.6135 \mathrm{U}+46.5787\left(\mathrm{R}^{2}=0.9924\right)$

$\mathrm{a}^{*}=3.4414 \mathrm{U}^{2}-4.5812 \mathrm{U}+15.5618\left(\mathrm{R}^{2}=0.9529\right)$

$\mathrm{C}^{*}=3.4862 \mathrm{U}^{2}-4.9067 \mathrm{U}+17.9347\left(\mathrm{R}^{2}=0.9313\right)$.

The inclusion of $0.5 \% \mathrm{DM}$ of urea in the ration determined a clearer meat by having greater $\mathrm{L}^{*}$ value (48.96), while adding $1.5 \% \mathrm{DM}$ of urea resulted in darker meat, with lower L* (42.53; Table 8). Although higher brightness was observed in the meat of lambs fed ration with $0.5 \% \mathrm{DM}$ of urea, the regression equation indicates that the maximum value of 48.67 in $\mathrm{L}^{*}$ can be obtained with the inclusion of $0.55 \% \mathrm{DM}$ of urea in the ration.

The lowest and the highest value for $\mathrm{a}^{*}$ were recorded in the diets with 1.0 and $1.5 \% \mathrm{DM}$ of urea (14.17 and 16.52; Table 8), which characterized lower and higher intensity of red color in the meat of lambs that received these rations, respectively. Based on the regression equation, the minimum value of 14.04 to $\mathrm{a}^{*}$ can be obtained by including $0.67 \% \mathrm{DM}$ of urea in the ration.

The coordinate $C^{*}$ showed a similar response pattern to the coordinate $\mathrm{a}^{*}$ relative to the urea levels, with lower and higher value for 1.0 and $1.5 \%$
DM of urea inclusion (16.23 and 18.52 respectively; Table 8). Thus, the meat had become brighter and more matte in lambs receiving diets with 1.0 and $1.5 \% \mathrm{DM}$ of urea, respectively. The value of $\mathrm{C}^{*}$ for the inclusion of $1.0 \% \mathrm{DM}$ of urea was very close to the minimum value estimated for this trait using the regression equation, which was 16.21 with the inclusion of $0.70 \% \mathrm{DM}$ of urea in the ration.

The meat of the lambs used in this study was redder and brighter, with higher values for the coordinate $\mathrm{a}^{*}$ and lower values for coordinate $\mathrm{C}^{*}$ when compared to results obtained by Souza et al. (2004a). Some studies suggest that the type of food can change the color of the meat. The greater intake of forage by grazing animals stimulates the increase of myoglobin levels in the muscles due to its higher levels of carotenoids (MORENO et al., 2008). Otherwise, some reports comment that the nature of the food (forage or grain) has little influence due to intense transformations that food suffers in the rumen (OSÓRIO et al., 2009). In this 
study, the darker (lower L*), redder (higher a*) and more matte (higher $\mathrm{C}^{*}$ ) profile of meat from lambs fed ration with $1.5 \% \mathrm{DM}$ of urea was determined by $\mathrm{pH}$, as described above. Probably these lambs had few glycogen stores in their muscles, which do not allow the meat to reach a $\mathrm{pH}$ low enough to determine normal color, regardless of animals age and meat tenderness (ZEOLA et al., 2007).

The measurement of meat color by the objective method determined that greater values for $\mathrm{L}^{*}$ are associated with paler meat, while greater values for $\mathrm{a}^{*}$ and $\mathrm{b}^{*}$ indicate a redder and yellower meat, respectively. The $\mathrm{L}^{*}$ coordinate is associated with the amount of water in the tissue and the progress of post mortem biochemical reactions. The coordinate $\mathrm{a}^{*}$ is an indicator of the color intensity and is related to the muscle oxymyoglobin content. The color of meat measured in relative values to the light reflection, represented by $\mathrm{L}^{*}$, is inversely proportional to the concentration of myoglobin in the muscle tissue, thus, the higher concentration of myoglobin reflects the smaller L* value (ODA et al., 2004). This must have occurred in the muscle tissue of lambs fed ration with $1.5 \%$ DM urea, as they produced meat with greater a* value and lower value of $\mathrm{L}^{*}$.

In general, lambs fed ration with $1.5 \% \mathrm{DM}$ of urea showed a darker (lower $\mathrm{L}^{*}$ ), redder (higher $\mathrm{a}^{*}$ ) and more matte (higher $\mathrm{C}^{*}$ ) meat. These characteristics may be associated with $\mathrm{pH}_{\mathrm{MEAT}}$ that regardless of being within the normal range was higher in meat from lambs fed ration with $1.5 \% \mathrm{DM}$ of urea. The correlation analysis indicated that the $\mathrm{pH}_{\mathrm{MEAT}}$ showed moderate and positive correlation with the coordinates $\mathrm{a}^{*}(\mathrm{r}=0.44 ; \mathrm{P}=0.0472)$, thus, the increase of $\mathrm{pH}_{\text {MEAT }}$ leads to a more intense red color. It was also found that the coordinate $\mathrm{a}^{*}$ showed moderate and negative correlation with the $\mathrm{L}^{*}$ coordinate $(\mathrm{r}=-0.56 ; \mathrm{P}=$ $0.0082)$, and high and positive correlation with $\mathrm{C}^{*}$ coordinate $(\mathrm{r}=0,95 ; \mathrm{P}<0.0001)$. Therefore, the increased intensity of red color causes the decrease of brightness and increase of saturation, resulting in darker and more matte meat.
The TL, WHC, CKL and SF were not affected $(\mathrm{P}>0.05)$ by urea levels in the ration (Table 8$)$, and showed mean values of $2.38 \%, 34.50 \%, 24.53 \%$ and $2.81 \mathrm{kgf} \mathrm{cm}^{-2}$, respectively. The $\mathrm{pH}$ can also affect other meat quality traits, such as TL, WHC, CKL and SF. Fernandes Júnior et al. (2013) observed higher CKL (9.58\%) in the meat of animals fed diets with high content of sunflower cake $(33.8 \% \mathrm{DM}$ of total diet), due to the lower $\mathrm{pH}$ of the meat (5.37). Except for CKL, the $\mathrm{pH}_{\mathrm{MEAT}}$ showed no correlation $(\mathrm{P}>0.05)$ with the meat quality traits. There was a moderate and positive correlation between $\mathrm{pH}_{\mathrm{MEAT}}$ and CKL $(\mathrm{r}=0.43 ; \mathrm{P}=0.0494)$, indicating that the increase of $\mathrm{pH}_{\mathrm{MEAT}}$ causes an increase in CKL, therefore less water bound to myoglobin, which contradicts the results of Fernandes Júnior et al. (2013). As the CKL is not affected by urea levels in the ration (Table 8), it is likely that the correlation between $\mathrm{pH}_{\mathrm{MEAT}}$ and $\mathrm{CKL}$ are associated with some individual variation in animals or meat samples that were analyzed.

The mean value for SF indicated that the meat of the lambs showed intermediate softness, because sheep meat with SF lower than $2.27 \mathrm{kgf} \mathrm{cm}^{-2}$ are classified as soft, and between 2.28 and $3.63 \mathrm{kgf}$ $\mathrm{cm}^{-2}$ are classified as intermediately soft (CEZAR; SOUSA, 2007). Given the lack of effect of urea levels on the SF (Table 8), the results for this trait were expected, since the animals were from similar genetic groups and slaughtered with the same SW. Whereas SF indicates the tenderness of the meat, it showed intermediate softness (mean of $2.82 \mathrm{kgf}$ $\mathrm{cm}^{-2}$ ), with adequate quality for commercialization.

\section{Conclusion}

The inclusion of up to $1.5 \%$ of urea in the ration, based on dry matter (DM), does not increase the carcass weight and yield, and the carcass compactness; and the weight of commercial cuts and non-carcass components of feedlot lambs.

The inclusion of $0.84 \% \mathrm{DM}$ of urea in rations for lambs is recommended to obtain maximum 
loin yield and meat with characteristics that are attractive to the consumer, which is characterized by the good intensity of red color and brightness. However, if consumers have a preference for lamb with a more intense red color, the inclusion of $1.5 \%$ DM of urea should be considered in the formulation of the ration.

\section{References}

ALMEIDA, T. R. V.; PEREZ, J. R. O.; CHLAD, M.; FRANÇA, P. M.; LEITE, R. F.; NOLLI, C. P. Desempenho e tamanho de vísceras de cordeiros Santa Inês após ganho compensatório. Revista Brasileira de Zootecnia, Viçosa, v. 40, n. 3, p. 616-621,2011.

ALVES, E. M.; PEDREIRA, M. S.; MOREIRA, B. S.; FREIRE, L. D. R.; LIMA, T. R.; SANTOS-CRUZ, C.L. Carcass characteristics of sheep fed diets with slow release urea replacing conventional urea. Acta Scientiarum Animal Science, Maringá, v. 36, n. 3, p. 303310, 2014.

ANDRADE, M. B.; MACEDO, F. A. F.; JOBIM, C. C.; LOMBARDI, L.; MACEDO, F. G.; GASPARINO, E. Características da carcaça e da carne de cordeiros terminados com dietas contendo diferentes proporções de silagens de grãos de milho. Acta Scientiarum Animal Sciences, Maringá, v. 31, n. 2, p. 183-189, 2009.

CANBOLAT, Ö.; KARABULUT, A. Effect of urea and oregano oil supplementation on growth performance and carcass characteristics of lamb fed diets containing different amounts of energy and protein. Turkish Journal of Veterinary Animal Science, Ankara, v. 34, n. 2, p. 119128, 2010.

CÉZAR, M. F.; SOUSA, W. H. Carcaças ovinas e caprinas: obtenção, avaliação e classificação. Uberaba: Agropecuária Tropical, 2007. $231 \mathrm{p}$.

CHALUPA, W. Problems in feeding urea to ruminants. Journal of Animal Science, Champaign, v. 27, n. 1, p. 207-219, 1968.

CLEMENTINO, R. H.; SOUSA, W. H.; MEDEIROS, A. N.; CUNHA, M. G. G.; GONZAGA NETO, S.; CARVALHO, F. F. R.; CAVALCANTE, M. A. B. Influência dos níveis de concentrado sobre os cortes comerciais, os constituintes não-carcaça e os componentes da perna de cordeiros confinados. Revista Brasileira de Zootecnia, Viçosa, v. 36, n. 3, p. 681-688, 2007.
COLOMER-ROCHER, F.; ESPEJO, M. D. Determinación del peso óptimo de sacrifício de los cordeiros procedentes del cruzamento Manchego x Raza Aragonesa en función del sexo. Revista ITEA, Zaragoza, v. 1, p. 219-235, 1972.

COSTA, R. G.; SANTOS, N. M.; SOUSA, W. H.; QUEIROGA, R. C. R.; AZEVEDO, P. S.; CARTAXO, F. Q. Qualidade física e sensorial da carne de cordeiros de três genótipos alimentados com rações formuladas com duas relações volumoso: concentrado. Revista Brasileira de Zootecnia, Viçosa, v. 40, n. 8, p. 1781-1787, 2011.

FASAE, O. A.; ADU, I. F.; AINA, A. B. J.; DIPEOLU, M.A. Growth performance, carcass characteristics and meat sensory evaluation of West African dwarf sheep fed varying levels of maize and cassava hay. Tropical Animal Health and Production, Houten, v. 43, n. 2, p. 503-510, 2011.

FERNANDES JÚNIOR, F.; RIBEIRO, E. L. A.; MIZUBUTI, I. Y.; SILVA, L. D. F.; BARBOSA, M. A. A. F.; PRADO, O. P. P.; PEREIRA, E. S.; PIMENTEL, P. G.; CONSTANTINO, C. Características de carcaça e qualidade da carne de cordeiros Santa Inês alimentados com torta de girassol em substituição ao farelo de algodão. Semina: Ciências Agrárias, Londrina, v. 34, n. 6, p. 3999-4014, 2013.

HAMM, R. Biochemistry of meat hydratation. Advances in Food Research Cleveland, Amsterdam, v. 10, n. 2, p. 335-443, 1960.

ÍTAVO, C. C. B. F.; MORAIS, M. G.; COSTA, C.; ÍTAVO, L. C. V.; MACEDO, F. A. F.; TOMICH, T. R. Características de carcaça, componentes corporais e rendimento de cortes de cordeiros confinados recebendo dieta com própolis ou monensina sódica. Revista Brasileira de Zootecnia, Viçosa, v. 38, n. 5, p. 898-905, 2009.

JENKINS, K. H.; PAS, K. J.; VANDER POL PAS, J. T.; VASCONCELOS, J. T.; PAS, S. A.; FURMAN, C. T.; MILTON, G.E.; ERICKSON, P. G. E.; KLOPFENSTEIN, T. J. Effect of degradable intake protein supplementation in finishing diets containing dried distillers grains or wet distillers grains plus soluble on performance and carcass characteristics. The Professional Animal Scientist, Amsterdam, v. 27, n. 4, p. 312-318, 2011.

LANDIM, A. V.; MARIANTE, A. S.; McMANUS, C.; GUGEL, R.; PAIVA, S. R. Características quantitativas da carcaça, medidas morfométricas e suas correlações em diferentes genótipos de ovinos. Ciência Animal Brasileira, Goiânia, v. 8, n. 4, p. 665-676, 2007. 
MACEDO, F. A. F.; SIQUEIRA, E. R.; MARTINS, E. N.; MACEDO, R. M. G. Qualidade de carcaças de cordeiros Corriedale, Bergamácia x Corriedale e Hampshire Down $\mathrm{x}$ Corriedale, terminados em pastagem e confinamento. Revista Brasileira de Zootecnia, Viçosa, v. 29, n. 5, p. 1520-1527, 2000.

MAGALHÃES, K. A.; VALADARES FILHO, S. C.; PAULINO, P. V. R.; PAULINO, M. F.; VALADARES, R. F. D. Performance, digestibility and carcass characteristics of feedlot dairy steers fed diets with different urea levels. Arquivo Brasileiro de Medicina Veterinária e Zootecnia, Belo Horizonte, v. 58, n. 5, p. 860-867, 2006.

MEDEIROS, G. R.; COSTA, G. R.; ANDRADE, M. G. L. P.; AZEVEDO, P. S.; MEDEIROS, A. N.; PINTO, T. F.; SOARES, J. N.; SUASSUNA, J. M. A. Estado de engorduramento da carcaça de ovinos Santa Inês e Morada Nova abatidos com diferentes pesos. Actas Iberoamericanas de Conservación Animal, Córdoba, v. 1, p. 243-246, 2011

MENDOZA JÚNIOR, N.; MAY, B. J.; SALISBURY, M. W.; ENGDAHL, G. R. The effect of protein level on feedlot performance and carcass characteristics of Texas Rambouillet ewes. The Texas Journal of Agriculture and Natural Resource, Stephenville, v. 20, p. 75-81, 2007.

MORENO, G. M. B.; BUZZULINI, C.; BORBA, H.; COSTA, A. J.; LIMA, T. M. A.; DOURADO, J. F. B. Efeito do genótipo e do teor de proteína da dieta sobre a qualidade da carne de cordeiros. Revista Brasileira de Saúde e Produção Animal, Salvador, v. 12, n. 3, p. 630640, 2011.

MORENO, G. M. B.; LOUREIRO, C. M. B.; SOUZA, H. B. A. Características qualitativas da carne ovina. Revista Nacional da Carne, São Paulo, v. 1, n. 381, p. 76-90, 2008.

NATIONAL RESEARCH COUNCIL - NRC. Nutrient requirements of sheep. 6. ed. Washington, D.C.: National Academy Press, 1985. 99 p.

NORO, M.; BERTINAT, R.; YAÑEZ, A.; SLEBE, J. C.; WITTWER, F. Non-protein nitrogen supplementation increases gluconeogenic capacity in sheep. Livestock Science, Amsterdam, v. 148, n. 3, p. 243-248, 2012.

NÚÑEZ, A. C.; MENCIO, P. R.; RENTERIA, I. D.; SOLÍS, A. S.; ORTEGA, M. L. Influencia de la suplementación sobre la ganancia de peso y calidad de la canal en borregos Dorper/Katahdin. Revista Científica UDO Agrícola, Puerto La Cruz, v. 7, n. 1, p. 245-251, 2007.
ODA, S. H. I.; BRESSAN, M. C.; MIGUEL, G. Z. Efeito do método de abate e do sexo sobre a qualidade da carne de capivara (Hydrochaeris hydrochaeris). Ciência e Tecnologia de Alimentos, Campinas, v. 24, n. 3, p. 341346, 2004.

OSÓRIO, J. C. S.; OSÓRIO, M. T. M.; SAÑUDO, C. Características sensoriais da carne ovina. Revista Brasileira de Zootecnia, Viçosa, v. 38, p. 292-300, 2009. Suplemento Especial.

REIS, R. A.; SILVA, S. C. Consumo de forragens. In: BERCHIELLI, T. T.; PIRES, A. V.; OLIVEIRA, S. G. (Ed.). Nutrição de ruminantes. 2. ed. Jaboticabal: FUNEP, 2006. p.7 9-109.

RIBEIRO, T. M. D.; COSTA, C.; MONTEIRO, A. L. G.; SILVA, M. G. B.; GILAVERTE, S.; PRADO, O. R. Componentes não constituintes da carcaça e cortes cárneos de cordeiros em diferentes sistemas de alimentação. Boletim da Indústria Animal, Nova Odessa, v. 66, n. 1, p. 11-19, 2009.

STATISTICAL ANALYSIS SYSTEM - SAS. Statistical Analysis System user's guide, version 9.0. Cary, Statistical Analysis System Institute, 2002. 513 p.

SANTOS, V. C.; EZEQUIEL, J. M. B.; PINHEIRO, R. S. B.; BARBOSA, J. C.; GALATI, R. L. Características de carcaça de cordeiros alimentados com grãos e subprodutos da canola. Acta Scientiarum. Animal Sciences, Maringá, v. 31, n. 4, p. 389-395, 2009.

SOUZA, P. P. S.; SIQUEIRA, E. R.; MAESTA, S. A. Ganho de peso, característica da carcaça e dos demais componentes corporais de cordeiros confinados alimentados com distintos teores de ureia. Ciência Rural, Santa Maria, v. 34, n. 4, p. 1185-1190, 2004a.

SOUZA, X. R.; BRESSAN, M. C.; PÉREZ, J. R. O.; FARIA, P. B.; VIEIRA, J. O.; KABEYA, D. M. Efeitos do grupo genético, sexo e peso ao abate sobre as propriedades físico-químicas da carne de cordeiros em crescimento. Ciência e Tecnologia de Alimentos, Campinas, v. 24, n. 4, p. 543-549, 2004b.

TURINO, V. F.; SUSIN, I.; PIRES, A. V.; MENDES, C. Q.; MORAIS, J. B.; OLIVEIRA JÚNIOR, R. C. Casca de soja na alimentação de cordeiros confinados: Desempenho e características da carcaça. Ciência Animal Brasileira, Goiânia, v. 8, n. 3, p. 495-503, 2007.

URANO, F. S.; PIRES, A. V.; SUSIN, I.; MENDES, C. Q.; RODRIGUES, G. H.; ARAUJO, R. C.; MATTOS, W. R. S. Desempenho e características da carcaça de cordeiros confinados alimentados com grãos de soja. Pesquisa Agropecuária Brasileira, Brasília, v. 41, n. 10, p. 1525-1530, 2006. 
VIVIAN, D. R.; GARCEZ NETO, A. F.; FREITAS, J. A.; FERNANDES, S. R.; ROZANSKI, S. Performance and serum chemistry profile of lambs fed on rations with increasing levels of urea. Semina: Ciências Agrárias, Londrina, v. 38, n. 2, p. x-x, 2017.

VOLTOLINI, T. V.; MORAES, S. A.; ARAÚJO, G. G. L.; OLIVEIRA, P. L. T.; PEREIRA, L. G. R. Urea levels in multiple supplement for lambs grazing on buffel grass. Acta Scientiarum Animal Sciences, Maringá, v. 32, n. 4, p. 461-465, 2010.

ZEOLA, N. M. B. L.; SOUZA, P. A.; SOUZA, H. B. A.; SILVA SOBRINHO, A. G. Parâmetros qualitativos da carne ovina: um enfoque à maturação e marinação. Revista Portuguesa de Ciências Veterinárias, Lisboa, v. 102, n. 563-564, p. 215-224, 2007.
ZIGUER, E. A.; ROLL, V. F. B.; BERMUDES, R. F.; MONTAGNER, P.; PFEIFER, L. F. M.; DEL PINO, F. A. B.; CORREAA, M. N.; DIONELLO, N. J. L. Desempenho e perfil metabólico de cordeiros confinados utilizando casca de soja associada a diferentes fontes de nitrogênio não-proteico. Revista Brasileira de Zootecnia, Viçosa, v. 41, n. 2, p. 449-456, 2012.

ZUNDT, M.; MACEDO, F. A. F.; ASTOLPHI, J. L. L.; MEXIA, A. A.; SAKAGUTI, E. S. Desempenho e características de carcaça de cordeiros Santa Inês confinados, filhos de ovelhas submetidas à suplementação alimentar durante a gestação. Revista Brasileira de Zootecnia, Viçosa, v. 35, n. 3, p. 928-935, 2006. 
